\title{
MEMPERLUAS MAKNA ZINA DALAM GUGATAN PERCERAIAN (Studi kasus putusan Pengadilan Agama Tigaraksa No. 1538/Pdt.G/2013/PA.Tgrs)
}

\author{
Umar Haris Sanjaya \\ Fakultas Hukum Universitas Islam Indonesia \\ Jogjakarta, Indonesia \\ umarharis@uii.ac.id
}

\section{Abstract}

This study focused on discussing the meaning of zina laws that existed at the Compilation of Islamic Law and Government Regulation No. 9 Year 1975 on the implementation of Law No. 1 Year 1974 on Marriage, which the courts in applying the word adultery should also look at the changing patterns of behavior and adultery today. Adultery should no longer be defined as sexual intercourse with the entry of male into the female sex, but the behavior of adultery was bermcam-wide one is oral sex. Behavior oral sex is a matter of a lawsuit against a husband and wife on the grounds of adultery lawsuit, but the court rejected it. This study contains the problem is how judges interpret the word adultery in making judgments in divorce? whether oral sex can be classified into the word adultery? The study found that oral sex by law can not be regarded as adultery, but the act of adultery into. Proof of adultery can only be recognized when the entity relationship entry into the male female sex. In conclusion, the judges interpret the meaning of the word adultery adultery per se, but the behavior of adultery are now widely different patterns and actions. Justice should not only look at the regulations simply make judgments, but look at the pattern of behavior or adultery committed in defining the word adultery.

Keywords: adultery, oral sex, meaning law

\section{PENDAHULUAN}

Salah satu putusnya sebuah hubungan perkawinan dapat terjadi apabila salah satu pihak baik itu suami atau istri mengajukan gugatan perceraian. ${ }^{1}$ Gugatan perceraian yang diterima oleh Pengadilan akan diuji dan disidangkan dengan maksud apakah perceraian itu sudah memenuhi alasan-alasan perceraian sebagaimana diatur pada Peraturan Pemerintah (PP) No. 9 Tahun 1975 Tentang pelaksanaan UndangUndang No. 1 Tahun 1974 tentang perkawinan pasal 19 dan Kompilasi Hukum Islam

1 Subekti, Pokok-Pokok Hukum Perdata, Ctk. Ketujuh Belas, PT. Intermasa, Jakarta, 1983, Hlm. 42, Jakarta, 1983, h. 42 
Pasal 116. ${ }^{2}$ Alasan perceraian yang dimaksud pada pasal 19 pada PP No. 9 Tahun 1975 adalah :

1. Salah satu pihak berbuat zina atau menjadi pemabok, pemadat, penjudi, dan lain sebagainya yang sukar disembuhkan;

2. Salah satu pihak meninggalkan pihak lain selama dua tahun berturut-turut tanpa izin pihak lain dan tanpa alasan yang sah atau karena hal lain diluar kemampuannya;

3. Salah satu pihak mendapat hukuman penjara lima tahun atau hukuman yang lebih berat setelah perkawinan berlangsung;

4. Salah satu pihak melakukan kekejaman atau penganiayaan berat yang membahayakan pihak lain;

5. Salah satu pihak mendapat cacat badan atau penyakit dengan akibat tidak dapat menjalankan kewajiban sebagai suami/isteri;

6. Antara suami dan isteri terus-menerus terjadi perselisihan dan pertengkaran dan tidak ada harapan akan hidup rukun lagi dalam rumah tangga.

Ketentuan tentang alasan-alasan perceraian yang sama juga diatur pada Kompilasi Hukum Islam (KHI) yaitu pada pasal 116. Hanya pada ketentuan ini ada beberapa ayat penambahan yaitu suami melanggar taklik talak dan peralihan agama atau murtad yang menyebabkan terjadinya ketidakrukunan rumah tangga. ${ }^{3}$ Apabila alasan-alasan diatas dapat dibuktikan didalam gugatan perceraian dan pembuktian dipengadilan, pengadilan sepatutnya memberikan putusan yang mengabulkan gugatan perceraian. ${ }^{4}$ Gugatan perceraian yang dikabulkan oleh hakim, terhitung saat itu juga sudah terjadi penghapusan perkawinan akibat putusan hakim. Atas hal itu, ketua pengadilan akan membuat surat keterangan kepada pegawai pencatatan di pencatatan perkawinan bahwa perkawinan telah hapus. ${ }^{5}$

Dari beberapa alasan-alasan diatas, ada satu alasan yang diatur pada ayat pertama yang mengatakan bahwa salah satu pihak berbuat zina. Artinya apabila ada suami atau isteri yang terikat hubungan perkawinan melakukan zina maka itu dapat

2 Amir Syarifuddin, Hukum Perkawinan Islam Di Indonesia, Ctk. Pertama, Prenada Media, Jakarta, 2006, h. 190

3 Kompilasi Hukum Islam Pasal 116.

4 Ibnu Qayyim Al-Jauziyah, Hukum Acara Peradilan Islam, Ctk. Kedua, Pustaka Pelajar, Yogyakarta, 2007, h. 15

${ }^{5}$ Peraturan Pemerintah Nomor 9 Tahun 1975 Tentang Pelaksanaan Undang-Undang Nomor 1 Tahun 1974 Tentang Perkawinan Pasal 14-18 
dijadikan alasan bagi salah satu pihak untuk mengajukan perceraian. Konteks kata zina sendiri sebenarnya adalah sebuah perbuatan persenggamaan antara pria dan wanita yang tidak terikat oleh hubungan perkawinan. Artinya seorang pria dan wanita tanpa adanya hubungan perkawinan tidak dibolehkan agama untuk bersenggama. ${ }^{6}$ Menurut hukum Islam zina merupakan hubungan seksual yang dilakukan dengan sadar, tanpa keraguan dan dilakukan atas dasar suka sama suka antara pria dan wanita yang tidak terikat secara syariat Islam. 7 Lebih tegas lagi dikatakan bahwa zina merupakan perbuatan dimana memasukkan ujung kemaluan pria kedalam kemaluan wanita tanpa ada hubungan yang sah. ${ }^{8}$

Ayat suci Al-quran dalam surat Al-Mu'minun ayat 5-7 Allah SWT berfirman yang jelas mengatakan bahwa "Dan orang-orang yang menjaga kemaluannya, kecuali terhadap istri-istri mereka atau budak yang mereka miliki, maka sesungguhnya mereka dalam hal ini tiada tercela. Barangsiapa mencari yang dibalik itu maka mereka itulahorang-orang yang melampaui batas". Ayat diatas menegaskan bahwa suatu hubungan suami isteri sepatutnya dilakukan kepada mereka yang sudah memiliki isteri atau bagi mereka yang sudah terikat hubungan perkawinan.

Muslim pada hadist no. 1695 meriwayatkan tentang perintah yang nabi Muhammad SAW anjurkan terhadap pelaku zina, hal ini diceritakan yang artinya"Seseorang mengakui perbuatan zina, yang dialami oleh Maiz di Zaman Rasulullah Shallallahu 'Alaihi Wasallamyaitu berzina dengan seorang budak wanita dari suatu kampung. Setelah melakukan perbuatan tersebut, akhirnya Ma'iz bin Malik Al Aslami pergi menemui Rasulullah shallallahu'alaihi wasallam seraya berkata,"Wahai Rasulullah, sesungguhnya aku telah menzhalimi diriku, karena aku telah berzina, oleh karena itu aku ingin agar anda berkenan membersihkan diriku." Namun beliau menolak pengakuannya. Keesokan harinya, ia datang lagi kepada beliau sambil berkata, "Wahai Rasulullah, sesungguhnya aku telah berzina." Namun beliau tetap menolak pengakuannya yang kedua kalinya. Lalu Rasulullah Shallallahu 'Alaihi Wasallam mengutus seseorang untuk menemui kaumnya dengan mengatakan: "Apakah kalian tahu bahwa pada akalnya Ma'iz ada sesuatu yang tidak beres yang kalian ingkari?"

\footnotetext{
6 Tamar Djaja, Tuntutan Perkawinan \& Rumah Tangga Islam, Ctk. Kedua, PT. Alma'arif, Bandung, 1982, h. 202

7 Neng Djubaedah, Perzinaan Dalam Peraturan Perundang-undangan di Indonesia Ditinjau dari Hukum Islam, Ctk. Pertama, Kencana Prenada Media Group, Jakarta, 2010, h. 119

8 Ibid.
} 
mereka menjawab, “Kami tidak yakin jika Ma'iz terganggu pikirannya, setahu kami dia adalah orang yang baik dan masih sehat akalnya." Untuk ketiga kalinya, Ma'iz bin Malik datang menemui Rasulullah Shallallahu 'Alaihi Wasallam untuk membersihkan dirinya dari dosa zina yang telah diperbuatnya. Lalu Rasulullah shallallahu 'alaihi wasallam pun mengirimkan seseorang menemui kaumnya untuk menanyakan kondisi akal Ma'iz, namun mereka membetahukan kepada beliau bahwa akalnya sehat dan termasuk orang yang baik. Ketika Ma'iz bin Malik datang keempat kalinya kepada beliau, maka beliau memerintahkan untuk membuat lubang ekskusi bagi Ma'iz. Akhirnya beliau memerintahkan untuk merajamnya, dan hukuman rajam pun dilaksanakan".

Oleh karena itu jelas tindakan berbuat zina yang ada pada Undang-Undang No. 1 Tahun 1974 dan Kompilasi Hukum Islam yang mereferensi dari Al-quran dan Hadist adalah perbuatan yang dilarang hukum dan agama. Sebagai tambahan, dalam kontek pemidanaan kata zina pada Kitab Undang-Undang Hukum Pidana (KUHP) pasal 284 sendiri juga tidak menunjukkan arti kata zina dengan jelas. Justru pada KUHP istilah zina menggunakan kata gendak (overspel). Gendak sendiri lebih cenderung terjadinya perbuatan perselingkuhan, bukan dijelaskan apa itu zina. Tercantum pada pasal 284 KUHP zina yaitu : ${ }^{9}$

1. Diancam dengan pidana penjara paling lama sembilan bulan :

a. Seorang pira yang telah kawin yang melakukan gendak (overspel), padahal pasal 27 BW berlaku baginya;

b. Seorang wanita yang telah kawin yang melakukan gendak padahal diketahui bahwa pasal 27 BW berlaku baginya;

c. Seorang pria yang turut serta melakukan perbuatan itu padahal yang turut bersalah telah kawinl

d. Seorang wanita yang telah kawin yang turut serta melakukan perbuatan itu, padahal diketahui olehnya bahwa yang turut bersalah telah kawin dan pasal 27 BW berlaku baginya.

2. Tidak dilakuan penuntutan melainkan atas pengaduan suami/isteri yang tercemar, dan bilamana bagi mereka berlaku pasal 27 BW, dalam tenggang tiga bulan diikuti dengan permintaan bercerai atau pisah meja dan ranjang karena alasan itu juga.

\footnotetext{
${ }_{9}^{9}$ Sosilo, KUHP dan KUHAP, Buana Press, Jakarta, 2008, h. 95.
} 
3. Terhadap pengaduan ini tidak berlaku pasal 72,73 , dan 75 .

4. Pengaduan dapat ditarik kembali selama pemeriksaan dalam sidang pengadilan belum dimulai.

5. Jika bagi suami-isteri berlaku pasal $27 \mathrm{BW}$, pengaduan tidak diindahkan selama perkawinan belum diputuskan karena perceraian atau sebelum putusan yang menyatakan pisah meja dan tempat tidur menjadi tetap.

Pada penelitian ini penulis ingin mencari formulasi kata zina yang dapat dipergunakan sebagai pertimbangan hakim dengan mengikuti praktek-praktek dan pola zina yang berbeda dari pengertian zina di peraturan perundang-undangan. Secara khusus praktek zina yang ingin diteliti adalah perilaku zina dalam konteks oral seks. Praktek oral seks menjadi perilaku seks yang juga dilakukan oleh masyakat di Indonesia. Salah satunya adalah kasus gugatan permohonan cerai yang dilakukan istri kepada suami dengan dasar gugatan/dalil perbuatan zina dalam bentuk oral seks. 10

Pada gugatan ini isteri selaku penggugat mengajukan cerai karena suami melakukan perbuatan zina. Isteri adalah ibu rumah tangga yang beralamat di Tangerang Selatan, Banten yang menggugat suaminya seorang pegawai negeri sipil. Sebelumnya mereka telah melangsungkan perkawinan yang sah menurut Agama Islam pada 10 September 1994 dan telah dicatatkan sesuai peraturan perundang-undangan yang berlaku. Selama berumah tangga mereka mempunyai 2 orang anak. Suami atau tergugat selama berumah tangga mempunyai tabiat yang kurang baik yaitu suka berbuat zina dengan wanita lain seperti pekerja seks komersial. Tidak hanya itu, tergugat selalu membuat dokumentasi pesta seks dari adegan ciuman hingga oral seks dalam bentuk foto di Handphone. ${ }^{11}$ Perbuatan zina itu tidak hanya dilakukan dengan satu pekerja seks saja, melainkan beberapa pekerja seks komersial lainnya. Terhadap kelakuan tergugat itu, penggugat dan tergugat sudah pisah ranjang selama 6 tahun meskipun mereka masih tinggal dalam 1 rumah.

Kelakuan tergugat yang selalu berzina dengan pekerja seks komersial ini memicu pertengkaran dan menimbulkan keinginan penggugat untuk bercerai. Pada akhirnya penggugat mengajukan gugatan cerai ke pada tergugat. Gugatan dimohonkan ke Pengadilan Agama Tigaraksa dengan mengajukan bukti 2 orang saksi, yaitu kakak

10 http://news.detik.com/berita/2517113/meski-ada-bukti-foto-pesta-seks-majelishakimtolak-gugatan-perceraian, artikel diambil pada 10 April 2015, 09.00 WIB

11 Ibid. 
kandung penggugat dan ayah kandung penggugat. Bukti printout foto suami sedang melakukan pesta seks yang isinya sedang beradegan ciuman dan beberapa foto sedang oral seks, bukti ini sudah dikuatkan dengan akta pernyataan notaris terhadap kebenaran alat bukti itu. Disamping foto, istri juga mengajukan bukti Short Message Service (SMS) dan Blackberry messengger (BBM) sebagai alat bukti foto di Handphone suami /tergugat. ${ }^{12}$ Kesemua alat bukti yang diajukan oleh istri/penggugat telah dilakukan uji forensik oleh ahli dibidang Information Technology (IT) dari Institute Teknologi Bandung yang dinyatakan original/bukan rekayasa yang turut hadir sebagai saksi ahli yang memberikan keterangan dibawah sumpah. ${ }^{13}$

Terhadap permohonan gugatan perceraian itu majelis hakim memutus dalam putusan No. 1538/Pdt.G/2013/PA.Tgrs bahwa majelis hakim menolak gugatan perceraian yang dimohonkan oleh isteri selaku penggugat. Majelis hakim menganggap bahwa bukti foto yang dijadikan alat bukti oleh penggugat yang menunjukkan adegan ciuman dan oral seks melalui BBM dan SMS chatting tidak mengandung unsur zina. Majelis hakim berpendapat bahwa foto tersebut tidak menunjukkan atau memunculkan masuknya alat kelamin pria kedalam wanita sebagai bukti adanya unsur perzinaan. Secara sederhana hakim cukup membuktikan bahwa yang namanya zina harus ada masuknya alat kelamin. Dengan demikian alat bukti foto itu tidak dapat digunakan sebagai alasan penggugat/isteri untuk menjadikan zina sebagai alasan perceraian sebagaimana dimaksud pada pasal $116 \mathrm{KHI}$.

Disamping alasan diatas majelis hakim berpendapat bahwa untuk membuktikan terjadinya perzinaan harus dibuktikan dengan 4 orang saksi yang melihat secara langsung pada saat berbuat zina dalam tempat dan waktu yang sama. Majelis hakim dalam putusan ini menolak bukti foto yang diajukan penggugat, sehingga majelis hakim memutuskan untuk menolak gugatan perceraian. Alasan majelis hakim mengacu pada firman Allah SWT pada Surat Q.S An-Nur ayat 4 yang artinya "dan orang-orang yang menuduh perempuan-perempuan yang baik (berzina) dan mereka tidak mendatangkan empat orang saksi, maka deralah mereka delapan puluh kali, dan janganlah kamu terima kesaksian mereka untuk selama-lamanya, mereka itulah orang-orang yang fasik".

Yang menjadi menarik untuk dikaji atas putusan No. 1538/Pdt.G/2013/PA.Tgrs sebagai obyek penelitian adalah pertimbangan hakim yang mengacu pada keterangan

12 Ibid.

13 Ibid. 
tidak adanya unsur zina pada foto tersebut karena majelis hakim menganggap oral seks bukanlah zina. Ditambahkan dalam pertimbangan hakim bahwa secara normative syar'i yang dapat dikatakan zina adalah hubungan seksual melalui pertemuan dua alat vital antara pria dan wanita diluar ikatan perkawinan. Dengan demikian jika 2 orang pria dan wanita berada di suatu tempat berdua-duan sambil bertelanjang, bahkan berciuman tanpa melakukan persenggamaan tidak termasuk kategori zina. ${ }^{14}$

Penulis ingin mengkrucutkan penelitian ini pada konteks makna kata zina sendiri, ,mengingat pola dan perilaku seks yang berubah dimasyarakat sehingga memungkinkan seseorang itu menyalurkan hasrat seks nya tidak dengan memasukkan alat kelamin, tetapi hanya sebatas oral seks. Ketika oral seks itu dijadikan dalil didalam permohonan cerai sebagai alasan telah terjadinya zina, maka perbuatan oral seks ini tidak dapat digunakan untuk membuktikan terjadinya zina sebagaimana diatur pada KHI pasal 116 dan PP No. 9 Tahun 1975 pasal 19. Sehingga ketika penggugat yang mengajukan gugatan cerai atas alasan zina, hanya sebatas zina yang memasukkan kelamin pria kedalam wanita saja yang dapat dikabulkan oleh majelis hakim.

Berdasarkan latar belakang diatas, letak permasalahan yang ingin diteliti diuraikan dalam pertanyaan sebagai berikut bagaimana hakim memaknai kata zina dalam membuat pertimbangan dalam gugatan perceraian ? apakah oral seks dapat diklasifikasikan kedalam kata zina?

\section{METODE PENELITIAN}

Penelitian ini dilaksanakan di Yogyakarta, Provinsi Daerah Istimewa Yogyakrta. Penelitian yang dilakukan adalah studi kepustakaan dengan mengkaji hukum normatif didalam peraturan perundang-undangan dengan mengkaitkan pada asas hukum dan menggunakan metode kualitatif. ${ }^{15}$ Pendekatan yang dipakai adalah pendekatan normatif, yakni menggunakan kata zina yang terdapat pada Kompilasi Hukum Islam pasal 116 dan PP No. 9 Tahun 1975 pasal 19 untuk dicari relevansinya dengan kata zina sebagaimana perilaku dan pola seks pada saat ini dispesifikan pada oral seks. ${ }^{16}$

\footnotetext{
14 Putusan No.1538/Pdt.G/2013/PA.Tgrs pada bagian pertimbangan putusan poin ke 3

${ }^{15}$ Suharsimu Arikunto, Prosedur Penelitian Suatu Pendekatan Praktek, Rineka Cipta, Jakarta, 1996, h. 144

16 Sri Mamudji, et, al., Metode Penelitian dan Penulisan Hukum, Badan Penerbit Fakultas Hukum Universitas Indonesia, Jakarta, 2005, h. 4
} 
Sumber data yang digunakan dalam penelitian ini adalah data sekunder berbentuk bahan hukum, yang terdiri atas : 17

a) Data sekunder yaitu berupa bahan hukum yang terbagi atas bahan hukum primer, sekunder, dan tersier yaitu :

1. Bahan hukum primer meliputi :
a. Putusan Pengadilan Agama No. 1538/Pdt.G/2013/PA.Tgrs
b. Undang-Undang No. 1 Tahun 1974
c. Peraturan Pemerintah No. 9 Tahun 1975
d. Kompilasi Hukum Islam

2. Bahan hukum sekunder terdiri dari penelitian, disertasi , tesis, buku, jurnal, artikel dan literatur pustaka lainnya yang berkaitan dengan permasalahan yang dibahas;

3. Bahan hukum bersifat tersier, yakni bahan hukum yang dapat menerangkan dan menjelaskan bahan hukum primer dan sekunder. ${ }^{18}$

Pengumpulan data penelitian ini, penulis mencoba dengan:

a. Studi pustaka yaitu mengkaji hasil penelitian hukum, jurnal, literatur yang berkaitan dengan objek yang diteliti.

b. Studi dokumen yaitu dengan mencari data-data, dokumen-dokumen resmi institusional, dan hal-hal lain yang terkait seputar dengan rumusan permasalahan.

Data yang diperoleh dari hasil penelitian, dianalisis dengan menggunakan metode diskriptif-kualitatif. ${ }^{19}$ Yaitu data yang diperoleh di lapangan dan di perpustakaan, disusun secara sistematis setelah diseleksi dan diurai, dipilah-pilah data, menelaah data, dan menghubungkan data tersebut untuk member makna atas penelitian berdasarkan objek permasalahan.

\section{PEMBAHASAN}

\section{Pengertian zina secara umum}

17 Soerjono Soekamto. Penelitian Hukum Normatif (Suatu Tinjauan Singkat)” ,PT Raja Grafindo Persada, Jakarta,2007, h. 13

18 Soerjono Soekanto, Sri Mamudji, Penelitian Hukum Normatif Suatu Tinjauan Singkat, Raja Grafindo Persada, cet. 10, Jakarta, 2007, h. 13.

19 Riyanto Adi, Metodologi Penelitian Sosial dan Hukum. Jakarta, Graint 2004. h. 128 
Pengertian mengenai zina banyak diulas pada beberapa kajian ilmu psikologi dan fiqih jinayat, fiqih muamalah, ${ }^{20}$ tetapi pemahaman zina secara makna hukum positif cenderung lebih kepada perilaku perselingkuhan semata. ${ }^{21}$ Secara istilah, ${ }^{22}$ zina diartikan sebagai sebuah persetubuhan yang dilakukan antara pria dan wanita dengan memasukkan kemaluan pria kedalam kemaluan wanita yang bukan istrinya. ${ }^{23}$ Para ulama Islam memberikan pengertian tentang zina berbeda-beda walaupun dengan substansi yang sama untuk memudahkan penulis menggunakan 4 mahzab yang ada di Indonesia. Mahzab maliki mengatakan bahwa zina adalah seorang mukallaf yang menyetubuhi farji yang bukan miliknya sah. Mahzab hanafi mengatakan zina adalah persetubuhan pria dan wanita pada kemaluan tanpa didasari syubhat kepemilikan. ${ }^{24}$

Maksud ulama yang secara substansi sama dalam memberikan pengertian zina ketika zina diartikan dengan sebuah persetubuhan yang dilakukan laki-laki dan dia sudah mukallaf terhadap wanita atau farji/kemaluan dimana perbuatan itu secara sadar sengaja dilakukan tanpa didasari kepemilikan (tali perkawinan). ${ }^{25}$ Artinya secara pemahaman syariah, persetubuhan yang dilakukan tanpa adanya kepemilikan atau ikatan perkawinan diartikan sebagai zina. ${ }^{26}$ Secara tegas maksud pelarangan zina dituangkan pada firman Allah SWT yang artinya "dan janganlah kamu mendekati zina, sesungguhnya zina itu adalah suatu perbuatan yang keji, dan suatu jalan yang buruk" (Q.S Al-Isra 32 :17).

Dapat kita ketahui bahwa pengertian zina yang ada pada Peraturan Pemerintah (PP) No. 9 Tahun 1975 Tentang pelaksanaan Undang-Undang No. 1 Tahun 1974 tentang perkawinan pasal 19 ayat (1) dan Kompilasi Hukum Islam Pasal 116 ayat (1) hanya

${ }^{20}$ Dalam perspektif ini, perzinahan masuk kedalam kategori seksualitas yang tidak beradab karena keluar dari konsep yang ada pada agama Islam karena sebelum Islam datang zina merupakan tindakan yang tidak dilarang. Lihat pada Arwani, Zina dan Kumpul Kebo dalam Perspektif Hukum Islam, Studi atas delik zina dan kumpul kebo dalam RUU KUHP 2005, skripsi, Fakultas Syariah, Universitas Islam Negeri Sunan Kalijaga, 2008, h. 4.

${ }^{21}$ Amir Syarifuddin,Hukum Perkawinan Islam di Indonesia (Antara Fiqh Munakahat dan UU Perkawinan, Prenada Media, Jakarta, 2006, h. 68

${ }^{22}$ Persetubuhan adalah sebuah ungkapan kasih untuk mempersatukan dimana rasa ini timbul dari dari dua pribadi yang bertekad untuk hidup bersama dalam suka dan duka, karena itu muncul istilah bersetubuh (menjadi satu tubuh), ia adalah milik saya dan saya adalah miliknya. Lihat pada Singgih D. Gunarsa, Psikologi Praktis : Anak, Remaja, dan Keluarga, BPK Gunung Mulia, Jakarta, 1991, h. 91-92.

${ }^{23}$ Neng Djubaedah, Perzinaan Dalam Peraturan Perundang-undangan di Indonesia Ditinjau dari Hukum Islam, Ctk. Pertama, Kencana Prenada Media Group, Jakarta, 2010, h. 8

${ }^{24}$ A. Djazli, Fiqih Jinayah, Grafindo Persada, Jakarta, 1997, h. 36.

${ }^{25}$ Wahbah Az-Zuhaili, Fiqih Islam Wa Adillatuhu, Ctk. Kesepuluh, Gema Insani, Jakarta, 2007, Hlm. 303

${ }^{26}$ Dijelaskan bahwa zina dilakukan bukan karena subhat tetapi didasari atas syahwat lihat pada Ali Zainudin, Hukum Pidana Islam, Sinar Grafika, Jakarta, 2007, h. 38 
sebatas tertulis "salah satu pihak berbuat zina atau menjadi pemabok, pemadat, penjudi, dan lain sebagainya yang sukar disembuhkan". Kata berbuat zina pada 2 ketentuan tersebut tidak mendapat rincian zina semacam apa yang diberlakukan, apakah zina sepanjang pemahaman ulama yang diakui di Indonesia atau masih terbuka bagi hakim untuk memberikan makna zina sesuai dengan kasus yang dihadapi hakim.

Untuk mengetahui lebih dalam pemahaman zina, penulis sertakan kajian unsurunsur yang melekat pada zina, dikemukakan oleh ulama mahzab di Indonesia bahwa zina mempunyai beberapa unsur seperti :27

1. Adanya persetubuhan (sexual intercouse) yang dilakukan didalam kemaluan perempuan yang tidak terikat perkawinan (heterosex). Artinya persetubuhan itu harus dilakukan dengan lawan jenis. Walaupun alat kemaluan yang masuk sedikit ataupun ada penghalang (kondom) selama penghalangnya tipis dan tidak menghalangi persenggamaan hal ini sudah dianggap zina.

2. Dilakukan dengan niat yang sengaja, artinya para pelaku secara sengaja dan niat untuk berzina walaupun sudah mengetahui bahwa yang disetubuhinya bukan haknya. Tetapi niat yang sengaja ini harus diikuti dengan perbuatan zina, jika tidak itu hanya sebatas niat dan pikiran saja maka tidak dikenai pertanggungjawaban zina. ${ }^{28}$

Dari 2 unsur diatas menimbulkan pertanyaan bagaimana jika pada unsur 1 mereka yang berbeda kelamin tidak sampai pada memasukkan alat kelamin walaupun sedikit, tetapi mereka hanya berciuman, berpelukan, atau oral seks ? pada konteks ini perbuatan yang dilakukan belum dapat dikatakan zina, yakni perbuatan zina yang dapat dijatuhi hukuman rajam atau dera. Tetapi mereka bisa dihukum yang bersifat edukatif. ${ }^{29}$ Kembali kepada pelaku zina itu sendiri, mengingat tanggung jawab hukum zina kembali pada pelakunya.

Secara hukum perbuatan zina akan dapat dikenai akibat hukumnya apabila zina itu dapat dibuktikan. Untuk membuktikan zina ini harus disertai dengan alat bukti yang khusus sebagaimana itu diatur didalam hukum acaranya pada pengadilan Agama, terlebih pada pembuktian zina sebagai alasan perceraian. Pembuktian zina

27 Wahbah Zuhaili, Fiqh Imalm Syafi'I, Almahira, Jakarta, 2010, h. 340-344

28 Dapat diketahui bahwa unsur zina terdapat persetubuhan yang dilakukan pria dan wanita diluar perkawinan, pelaku baligh, cakap hukum/mukallaf, berakal, dilakukan sadar, sengaja, dilakukan oleh manusia yang berbeda kelamin, perbuatan zina terhindar dari syubhat, pelaku mengetahui bahwa zina itu dilarang. Ibid

29 Ibid., h. 345. 
menggunakan asas in flagrante delicto yaitu pembuktian terhadap zina harus alat bukti saksi. ${ }^{30}$ Saksi tersebut haruslah saksi yang benar-benar menyaksikan peristiwa zina itu secara fisik sedang melakukan zina agar kesaksiannya mempunyai nilai kekuatan pembuktian. ${ }^{31}$

Maksud dari asas ini sesuai dengan firman Allah SWT dalam surat An-Nisa ayat 15 yang artinya "Dan para perempuan yang melakukan perbuatan keji di antara perempuan-perempuan kamu, hendaklah terhadap mereka ada 4 (empat) orang saksi di antara kamu (yang menyaksikannya). Apabila mereka telah memberi kesaksian, maka kurunglah mereka (perempuan itu) dalam rumah sampai mereka menemui ajalnya, atau sampai Allah SWT memberi jalan (yang lain) kepadanya."

Pada prakteknya, pembuktian zina haruslah dilakukan disidang pengadilan Agama. Dalam hal gugatan perceraian karena alasan zina pihak yang mendalilkan terjadinya zina berkewajiban membuktikan kebenaran peristiwa tersebut. Dalam sidang pengadilan ada 2 landasan yang dipakai untuk membuktikan zina yakni landasan positif dan landasan fiqh. ${ }^{32}$ Landasan positif yang dimaksud adalah pembuktian yang ada pada pasal 54 Undang-Undang No. 50 Tahun 2009 tentang Pengadilan Agama. Artinya bentuk-bentuk bukti yang bisa dipakai sebagai bukti adalah pembuktian yang berlaku hukum acara di Pengadilan Agama, kecuali ada yang diatur secara khusus. ${ }^{33}$

Disamping landasan positif, pengadilan agama mengenal landasan fiqh sebagai dasar pembuatan pertimbangan. Pada landasan fiqh, ${ }^{34}$ membuktikan perbuatan zina hakim akan menggunakan ijtihad ulama untuk menentukan terjadinya zina. Zina dibuktikan dengan 4 pembuktian yaitu saksi, pengakuan, qarinah, dan pembuktian li'an. ${ }^{35}$

pembuktian saksi pada kasus perzinaan ini telah disepakati oleh para ulama bahwa untuk membuktikan zina diperlukan 4 orang saksi. ${ }^{36}$ Sebagaimana dijelaskan

\footnotetext{
30 Penuduhan zina tidak dapat didasarkan hanya pada sebuah opini atau kesimpulan atas sebuah peristiwa

${ }^{31}$ M. Yahya Harahap, Kedudukan Kewenangan Dan Acara Peradilan Agama, Ctk. Keempat, Sinar Grafika, Jakarta, 2007, h. 320-323.

32 Muhammad Saifullah, Mohammad Arifin dan Ahmad Izzauddin, Hukum Islam Solusi Permasalahan Keluarga, Ctk. Pertama, UII Press, Yogyakarta, 2005, h. 60.

33 Ibid.

34 Fauzan Al-anshari Abdurrahman Madjrie, Hukuman bagi pezina dan penuduhnya, Kahirul Bayan, Jakarta, 2002, h. 6.

35 Wahbah Zuhaili, op.,cit., hlm. 326-327.

${ }^{36}$ A. Djazuli, Fiqh Jinayah (Upaya Menanggulangi Kejahatan dalam Islam), Ctk. Kedua, PT. Raja Grafindo Persada, Jakarta, 1997, h. 59.
} 
pada Q.S An-Nur ayat 13 yang artinya "Mengapa mereka (yang menuduh itu) tidak datang membawa 4 (empat) saksi?. Oleh karena mereka tidak membawa saksi-saksi, maka mereka itu dalam pandangan Allah SWT adalah orang-orang yang berdusta." Syarat keempat orang saksi itu mereka haruslah : laki-laki, ${ }^{37}$ mukallaf (baligh dan berakal dan mampu bertanggung jawab), adil, merdeka, beragama Islam, kesaksian yang sama terhadap perbuatan zina, memberikan keterangan dalam satu majelis persidangan, tidak dalam tempo waktu yang kadaluwarsa, ${ }^{38}$ mereka mempunyai kompetensi untuk bersaksi, ${ }^{39}$ dan kesaksian mereka mampu untuk meyakinkan hakim. ${ }^{40}$

Pendapat ulama dalam landasan fiqh tentang pembuktian zina terjadi perbedaan pada sisi pernyataan kesaksian. Menurut imam ahmad dan abu hanifah, keempat saksi harus menyatakan bahwa mereka menyatakan adanya perzinaan. Berbeda dengan pendapat diatas, imam malik dan imam syafii cukup mengambil 1 pengakuan saksi dalam penentuan perzinaan. ${ }^{41}$ dari 2 landasan hukum yang dipakai untuk membuktikan zina, kedua-duanya mensyaratkan harus dapat meyakinkan hakim didalam membuat pertimbangan hukumnya. Landasan positif dan landasan fiqh menjadi alat analisis yang berbeda dalam mencari pembuktian zina, tetapi kedua landasan itu mampu untuk meyakinkan hakim mencari kebenaran untuk pembuktian zina.

pada ujungnya, pertimbangan dan putusan hakimlah yang dapat menentukan perbuatan zina itu terbutkti atau tidak sebagai alasan pada gugatan perceraian . ${ }^{42}$ Hakim bertindak sebagai lembaga pengadilan di negara Indonesia yang berwenang untuk memutus perceraian sebagaimana diatur pada Peraturan perndang-undangan.

\section{Pengertian oral seks}

Kajian mengenai oral seks sudah banyak dikaji oleh peneliti hukum terutama pada kajian hukum islam. Oral seks yang dimaksud lebih kepada kajian perpektif hukum

\footnotetext{
${ }^{37}$ Jumhur ulama mensyaratkan saksi haruslah 4 orang laki-laki, tetapi ada beberapa ulama yang membolehkan saksi itu 3 laki-laki dan 2 perempuan atau 2 laki-laki dan 4 perempuan

${ }^{38}$ Imam syaifi'I , imam malik tidak mengenal kadaluwarsa dalam kesaksian perzinaan.

${ }^{39}$ Kompetensi artinya menyaksikan secara langsung, hal ini untuk menjaga dari kesaksian yang syubhat.

40 Dalam membuat pertimbangan kesaksian terjadinya perzinaan dilihat dari cara melakukan perzinaan, waktu kejadian, dan tempat kejadiannya.

41 Haliman, Hukum Pidana Sjari'at Islam Menurut Adjaran Ahlus Sunnah,Ctk. Pertama, BulanBintang, Jakarta, 1971, h. 390

42 Muhammad Syaifuddin, Sri Turatmiyah, Annalisa Yahanan, Hukum Perceraian, Ctk. Kedua, Sinar Grafika, Jakarta, 2014, h. 17-19
} 
islam atau kajian perbandingan dengan para pendapat ulama-ulama fiqh. ${ }^{43}$ Pada kajian ini tidak akan membahas oral seks secara mendalam, penulis mengkaji oral seks lebih kepada perbuatan yang bisa dijadikan ke alasan perzinaan. Mengingat oral seks pada kasus yang diteliti penulis dilakukan oleh mereka berlainan jenis dan masuk kepada kategori diluar batas kepatutan dalam hubungan perkawinan.

Kata oral seks diambil dari gabungan 2 buah kata yaitu seksual dan oral, seksual diartikan dengan syahwat dan nafsu birahi untuk melakukan hubungan seks. Oral diartikan dari kata oralisme berati mulut atau lisan dimana itu diartikan melakukan sesuatu dengan menggunakan mulut. ${ }^{44}$ Secara sederhana oral seks diartikan dengan sebuah aktifitas seksual yang menggunakan oral baik itu bibir, lidah gigi, bahkan hingga kerongkongan kepada alat kelamin suntuk memberikan stimulan seks. Oral seks dilakukan sebagai bagian dari aktivitas "pemanasan" sebelum dilakukannya persetubuhan bahkan dewasa ini oral seks dilakukan sebagai pengganti persetubuhan. 45

Oral seks yang secara umum diketahui dengan aktifitas dimana seorang wanita menghisap alat kelamin (penis dan buah zakar) pria, perilaku ini dikenal dengan istilah fellatio. Perilaku ini menjadi praktek yang sering dilakukan oleh mereka pasangan yang suka oral seks. Disamping itu ada juga perilaku yang sebaliknya yaitu dimana si pasangan pria yang menjilati alat kelamin (vagina dan clitoris) wanita. Perilaku ini dikenal dengan istilah cunnilingus yang artinya menjilat vulva. ${ }^{46}$

Secara psikologis perilaku kedua perilaku oral seks diatas dilakukan karena tindakan oral seks menimbulkan sensasi yang luar biasa bagi pasangan masing-masing. Hal ini berdasarkan pada penelitian secara sederhana yang dilakukan pada pasangan menikah bahwa oral seks adalah seks yang digemari. Alasan dari mereka melakukan

\footnotetext{
${ }^{43}$ Kebanyakan kajian oral seks dilihat dari sisi hukum islam yang dibandingkan dengan pendapat ulama seperti studi komparasi dengan pemikiran shahid athar, pemikiran an-najmi, Ainul Ghurri, Pemenuhan Kebutuhan Seksual dengan cara oral studi terhadap fatwa syaikh an-najmi dalam tinjauan hukum islam, skripsi, Fakultas Syari'ah, Universitas Islam Negeri Sunan Kalijaga, 2008, h. 38.

44 Iin Ernawati, Oral seks di dalam perkawinan dalam pandangan masyarakat serta kedudukannya menurut perspektif hukum Islam studi kel. Ciater kecamatan serpong, skripsi, Fakultas Syari'ah dan Hukum, Universitas Islam Negeri Syarif Hidayatullah, Jakarta, 2007, h. 64.

${ }^{45}$ Oral seks menggantikan persetubuhan karena salah satu pasangan yaitu si wanitanya sedang haid atau alasan lain yang menyebabkan wanita tidak dapat melakukan hubungan seks. Ainul Ghurri, op.,cit., 38-39

46 Iin Ernawati, op.,cit., h. 40-41
} 
oral seks karena pasangan itu ingin merasakan seks variasi yang berbeda dan menimbulkan rangsangan seks yang hebat. ${ }^{47}$

Menarik benang merah tentang oral seks didalam peraturan perundangundangan, hingga saat ini tidak ada persinggungan dengan oral seks didalam peraturanperundang-undangan. Mengingat oral seks bukan bagian dari perbuatan yang melawan hukum, ${ }^{48}$ bahkan Agama Islam sendiri tidak ada hukum yang jelas untuk melarang ataupun membolehkan oral seks. Beberapa pendapat ulama yang berbeda pendapat mengenai hukum boleh tidaknya oral seks didalam Islam mereka berdasarkan pada Q.S Al-Baqarah ayat 223 yang artinya "istri-istrimu adalah ladang bagimu, maka datangilah ladangmu itu kapan saja dengan cara yang kamu sukai".

Terhadap ayat diatas para ulama berpendapat ada yang membolehkan untuk dilakukannya oral seks, hal ini didasari atas pada prinsipnya suami istri boleh menikmati seluruh tubuh pasangannya dengan cara apapun yang diinginkan kecuali anal seks. Adapun yang berpendapat bahwa oral seks dilarang karena dikhawatirkan itu menjilat najis yang bercampur di alat kelamin. Quraish Shihab berpendapat bahwa oral seks yang dilakukan oleh pasangan suami istri bukan suatu yang diharamkan, sepanjang tidak keluar dari etika normal dan kesehatan. ${ }^{49}$

Pendapat yang sama mengatakan bahwa oral seks bisa juga perilaku penyimpangan seks yang ada dimasyarakat. ${ }^{50}$ Walaupun oral seks tidak ada hukum atau dalil yang jelas tentang pengharamannya tetapi ini bagian dari perbuatan seks. Oral seks menurut pendapat ulama menghukumnya dengan istilah perbuatan yang dibenci dan tidak bermoral. ${ }^{51}$ Mereka masih membuka kemungkinan untuk membolehkan oral seks karena perbuatan ini dikatakan sebagai hubungan seksual yang dilarang, mengingat yang sangat jelas dilarang adalah seks melalui anus (dubur). ${ }^{2}$

Secara garis besar, penulis mengkaji bahwa oral seks bagian dari perbuatan yang ada pada tingkat kesamaan dengan hubungan seksual, walaupun hubungan seksual ini

\footnotetext{
47 Marzuki Umar Sa'abah, Seks dan kita, Gema Insani Press, Jakarta, 2008, hlm. 446. Dimana mengutip dari polling toto Handoyo Kusumajaya dalam artikelnya cegah kehamilan dengan oral seks.

${ }^{48}$ Tidak ditemukan secara khusus peraturan perundang-undangan yang melarang perbuatan oral seks, semua kajian oral seks lebih kepada kajian psikologis suami istri dan kajian hukum perspektifiIslam. ${ }^{49}$ Quraish shihab, anda bertanya, quraish menjawab berbagai masalah keislaman, Al-Bayan, Bandung, 2003, hlm. 222-228.

50 Iin Ernawati, op.,cit., h. 68

${ }^{51}$ Asmu'I, oral seks dalam pandangan hukum islam dan medis, abla publisher, Jakarta, 2004, hlm. 76. 52 Ibid.
} 
tidak digambarkan persetubuhan atau persenggamaan. Tetapi hubungan seksual ini dilakukan dengan dasar untuk mencari variasi hubungan seks yang berbeda. Dalam oral seks ini juga menimbulkan nafsu dan syahwat yang sama seperti persetubuhan, walaupun ada pendapat bahwa oral seks dilakukan sebagai bentuk pemanasan (foreplay) . sesungguhnya tidak demikian, karena oral seks dapat pula dikatakan sebagai bentuk pelampiasan seksual, hal ini berlaku jika istri sedang dalam halangan seperti haid atau halangan lainnya. Maka oral seks disini sepatutnya bukan sebagai pemanasan sebelum persetubuhan, melainkan sebagai pelampiasan seks.

\section{Analisis oral seks sebagai alasan perceraian karena zina}

Memerlukan kajian dan perbandingan yang mendalam untuk bisa mennormakan oral seks sebagai zina pada hukum positif atau peraturan perundang-undangan, khususnya pada Peraturan Pemerintah (PP) No. 9 Tahun 1975 Tentang pelaksanaan Undang-Undang No. 1 Tahun 1974 tentang perkawinan pasal 19 dan Kompilasi Hukum Islam pasal 116. Hal ini tentu harus melalui mekanisme judicial review di Mahkamah Konstitusi, dan itu tentu tidak mudah. Tapi penulis ingin memberikan alasan itu dengan sebuah gambaran pada kasus yang diteliti ini dimana pada kasus putusan ini seorang istri mengajukan gugatan cerai terhadap suaminya dengan menggunakan alasan zina. Zina yang dimaksud sebagai alasan, ternyata dibuktikan dengan tindakan oral seks.

Isteri atau penggugat mengajukan gugatan cerai dan hadhanah pada tanggal 22 juni 2013 dan telah terdaftar di Kepaniteraan Pengadilan Agama Tigaraksa dalam register perkara nomor 1538/Pdt.G/2013/PA. Tgrs, tanggal 24 Juni 2013. Alasan gugatan dari penggugat :53

1. Bahwa penggugat dan tergugat telah melangsungkan perkawinan secara sah menurut agama islam pada tanggal 10 September 1994, dan perkawinan antara penggugat dan tergugat telah dicatat oleh Pejabat Pencatat Nikah Kantor Urusan Agama Kecamatan Regol.

2. Bahwa oleh karena perkawinan antara penggugat dan tergugat telah dilaksanakan menurut agama islam dan perkawinan tersebut telah dicatatkan, maka perkawinan antara penggugat dan tergugat adalahsah dan telah sesuai dengan ketentuan Pasal 2 ayat 1 Undang-Undang Nomor 1 Tahun 1974 tentang Perkawinan.

${ }^{53}$ Dikutip dari putusan No. 1538/Pdt.G/2013/PA.Tgrs 
3. Bahwa setelah melangsungkan perkawinan, penggugat dan tergugat bertempat tinggal di Kota Tangerang Selatan, Banten.

4. Bahwa selama berumah tangga, penggugat dan tergugat telah melakukan hubungan suami istri, sehingga dilahirkan 2 orang anak.

5. Bahwa pada awalnya, rumah tangga penggugat dan tergugat harmonis, namun ternyata tergugat mempunyai tabiat yang kurang baik, yaitu tergugat adalah seorang pezina. Yang suka berbuat zina dengan wanita pekerja seks komersial dan ketika berhubungan badan dengan wanita pekerja seks komersial tersebut, tergugat selalu membuat dokumentasi pesta seks mulai dari adegan ciuman hingga oral seks berupa bentuk foto di handphone merek Blackberry Bold 9000.Dan dari foto tersebut penggugat mengetahui suatu fakta bahwa tergugat sering melakukan perzinahan dengan wanita pekerja seks komersial. Perbuatan zina tersebut tidak hanya dilakukan tergugat dengan satu pekerja seks komersial, namun dilakukan tergugat dengan beberapa pekerja seks komersial yang lain.

6. Bahwa akibat kelakuan tergugat yang selalu berzina dengan pekerja seks komersial, mengakibatkan perkawinan antara penggugat dan tergugat tidak harmonis. Maka penggugat dan terguggat pisah ranjang kurang lebih 6 (enam) tahun yang lalu meskipun penggugat dan terguggat masih tinggal 1 (satu) rumah, namun antara penggugat dan terguggat sudah tidak ada komunikasi yang baik.

7. Bahwa kelakuan tergugat yang berzina dengan pekerja seks komersial menjadi pemicu perselisihan dan pertengkaran antara penggugat dan tergugat, sehinga tujuan perkawinan tidak sesuai lagi sebagaimana dikehendaki pada pasal 1 UndangUndang 1 tahun 1974 dan pasal 3 KHI.

8. Penggugat menderita karena dikhianati tergugat, yang berzina dengan Pekerja Seks Komersial .

9. Alasan gugatan cerai dalam perkara ini adalah jelas, yaitu tergugat telah berzina dengan pekerja seks Komersial, akibatnya memicu perselisihan dan pertengkaran. ${ }^{54}$ Sehingga jelas alasan penggugat menggugat dengan dalil "salah satu pihak berbuat zina" dan /atau antara suamu dan istri terus menerus terjadi perselisihan dan pertengkaran dan tidak ada harapan akan hidup rukun.

${ }^{54}$ Dikutip dari salinan putusan No. 1538/Pdt.G/2013/PA.Tgrs, h. 5 
Untuk menjadi pertimbangan hakim, penggugat memberikan bukti-bukti yang dapat dijadikan alasan untuk menguatkan gugatan :55

1. Fotokopi kutipan akta nikah nomor -, tanggal 10 September 1994, atas nama tergugat dan penggugat yang dikeluarkan oleh Kantor Urusan Agama Kecamatan Regol, Kotamadya Bandung, telah dicocokkan dengan aslinya dinazegelen dan bermaterai cukup, diberi tanda (P.1).

2. Fotokopi kartu keluarga nomor-, atas nama kepala keluarga tergugat yang dikeluarkan oleh Camat Ciputat Timur, Kota Tangerang Selatan tanggal 19 Juni 2013, telah dicocokkan dengan aslinya dinazegelen dan bermaterai cukup, diberi tanda (P.2).

3. Fotokopi kutipan akta kelahiran nomor -, atas nama anak I penggugat dan tergugat yang dikeluarkan oleh Kepala Kantor Catatan Sipil Pemerintah Kotamadya Dati II Bandung tanggal 16 Juli 1996, telah dicocokkan dengan aslinya di nazegelen dan bermaterai cukup diberi tanda(P.3).

4. Fotokopi kutipan akta kelahiran nomor -, atas nama anak II penggugat dan tergugat yang dikeluarkan oleh Kepala Dinas Kependudukan Kota Bandung, telah dicocokkan dengan aslinya di nazegelen dan bermaterai cukup diberi tanda (P.4).

5. Fotokopi berita acara tentang penyumpahan tanggal 15 Agustus 2011 atas nama yang bersumpah tergugat telah dinazegelen dan bermaterai cukup diberi tanda (P.5).

6. Fotokopi surat keterangan nomor-, tanggal 27 September 2013 yang dikeluarkan oleh Kepala SMPI IPL Jakarta, telah dicocokkan dengan aslinya dinazegelen dan bermaterai cukup diberi tanda (P.6).

7. Print outfoto pesta seks yang beradegan ciuman hingga oral seks, BBM (Blackberry Messengger), dan SMS(Short Message Service)chatting tergugat dengan perempuan pihak ketiga yaitu wanita pekerja seks komersial dari handphone merek Blackberry Bold 9000 diberi tanda (P.7).

8. Fotokopi akta pernyataan notaris nomor 06 tanggal 09 Desember 2013 telah dicocokkan dengan aslinya dinazegelen dan bermaterai cukup diberi tanda (P.8).

55 Ibid., h. 32 
Disamping mengajukan bukti surat, penggugat juga telah menghadirkan 2 (dua) orang saksi keluarga yaitu dari kakak kandung penggugat, ayah kandung penggugat dan 1 orang saksi ahli di persidangan.

Pertimbangan hakim pada putusan No. 1538/Pdt.G/2013/PA.Tgrs sudah menggambarkan pertimbangan hakim yang berlandaskan hukum yang baik, hanya saja hakim tidak berani mengambil keberanian dalam melihat fakta. Ada 4 pertimbangan hakim yang penulis dapatkan sebagai kajian pada penelitian ini yaitu :

1. Hakim menimbang bahwa bukti elektronik foto, BBM, dan SMS itu dapat diterima sebagai alat bukti yang sah. Hal ini didasari pada pasal 1 butir 4 Undang-Undang No. 11 tahun 2008 tentang Informasi dan Transaksi Elektronik yang mengatakan bahwa SMS, BBM, dan Foto itu termasuk dari dokumen elektronik. ${ }^{56}$ Foto printout yang didapat dari BBM dan kiriman SMS chating juga dikuatkan didalam pertimbangan hakim sebagai alat bukti yang sah sesuai hukum acara yang berlaku di Indonesia. Hal ini didasari majelis hakim berdasarkan pasal 5 ayat (1) yang mengatakan bahwa hasil cetak dari dokumen elektronik dan atau hasil cetaknya adalah alat bukti hukum yang sah, hal ini merupakan perluasan dari alat bukti hukum sebagaimana berlakunya hukum acara di Indonesia. ${ }^{57}$ Bukti foto, BBM, dan SMS chating yang diajukan oleh penggugat secara hukum diterima oleh majelis hakim, apalagi bukti itu telah diuji oleh ahli IT forensik dari Institut Teknologi Bandung. ${ }^{58}$

2. Untuk pertimbangan tentang zina, hakim menimbang dengan memberikan beberapa pertimbangan :

a. Secara normatif syar'I bahwa perzinaan adalah hubungan seksual melalui pertemuan dua alat vital antara pria dan wanita di luar ikatan perkawinan, sehingga seandainya dua orang pria dan wanita berada disuatu tempat berdua-duaan sambil bertelanjang, bahkan bercium-ciuman tanpa melakukan persenggamaan atau oral itu tidak masuk kategori zina.

\footnotetext{
${ }^{56}$ Dokumen elektronik adalah setiap infornasi elektronik yang dibuat, diteruskan, dikirimkan, diterima, atau disimpan dalam bentuk analog digital, elektromagnetik, optikal, atau sejenisnya yang dapat dilihat ditampilkan, dan atau didengar melalui computer atau system elektronik, termasuk tetapi tidak terbatas pada tulisan, suara, gambar, peta, rancangan, foto, atau sejenisnya, huruf, tanda, angka, kode akses, symbol atau perforasi yang memiliki makna atau arti atau dapat dipahami oleh orang yang mampu memahaminya.

57 Undang-Undang No. 11 tahun 2008 tentang Informasi dan Transaksi Elektronik pasal 5 ayat (2).

58 Sebagaimana dalam pertimbangan hakim pada pasal 6, 15, dan 16 yang intinya dokumen elektronik harus dapat dijamin keontentikannya, keutuhannya, dan ketersediaanya harus diuji secara forensic sebagai bentuk pemenuhan syarat formil dan syarat materiil.
} 
b. Zina disebutkan sebagai masalah sensitif, sehingga ini sangat krusial dalam pembuktiannya. Pembuktian zina membutuhkan 4 orang saksi yang mengetahui dan melihat secara langsung terjadinya perzinaan. tidak boleh hanya sekedar melihat pria dan wanita berdua-duaan dikamar saja, namun harus melihat secara langsung terjadinya persetubuhan. Sebagaimana Q.S AnNur menerangkan pada ayat 4.

3. Mengenai keterangan saksi, ${ }^{59}$ saksi yang dihadirkan oleh penggugat dinyatakan oleh hakim tidak memenuhi syarat materiil sebagai alat bukti saksi. Karena saksi yang dihadirkan tidak berdasarkan pada apa yang dilihat, didengar, dan atau dialami oleh saksi. ${ }^{60} \mathrm{Hal}$ ini melihat dari keterangan saksi penggugat yang hanya menerangkan kesaksian berdasarkan curhat dari penggugat dan menyimpulkan dari foto yang dilihat saksi.

4. Terhadap keterangan ahli, hakim menimbang bahwa keterangan ahli diperlukan hanya untuk meyakinkan majelis hakim tentang fakta hukum saja. Terhadap keterangan ahli yang disampaikan, hakim berpendapat bahwa secara fakta terhadap 2 pertimbangan hakim diatas mengenai pembuktian zina tidak ada perilaku zina. Hakim mengatakan hal yang terjadi pada bukti foto, BBM, SMS chatting itu sebagai pergaulan yang melampaui batas-batas secara etika islam.

Hakim melihat bahwa bukti foto, BBM, SMS chating dapat diterima sebagai alat bukti yang sah. Hakim pun melihat dan memperhatikan alat bukti dokumen itu dan menyimpulkan tidak terdapat unsur-unsur zina. Atas 4 pertimbangan hakim diatas, majelis mempunyai kesimpulan bahwa alasan perceraian karena tergugat seorang pezina atau suka berbuat zina dinyatakan tidak terbukti. ${ }^{61}$

Sangat ironi bagi penggugat yang tidak dapat bercerai secara hukum karena alasan penggugat tidak dapat dibuktikan sesuai hukum acara yang berlaku. Walaupun dengan keyakinan terhadap gambar yang dibuktikan sudah sah secara hukum sebagai alat bukti terdapat kegiatan seks tergugat dengan perilaku oral seks. Oral seks tidak memenuhi unsur zina sebagaimana dikaji pada tulisan diatas, tetapi kita bisa mengetahui bahwa ini perbuatan mendekati zina. Oral seks dapat dikatakan sebagai

\footnotetext{
${ }^{59}$ Berlaku asas in flagrante delicto yang artinya tuduhan zina harus dibuktikan dengan alat bukti saksi, supaya pembuktian saksi itu mempunyai kekuatan pembuktian maka saksi harus menyaksikan secara langsung

60 Sesuai dengan asas testimonium de auditu Berdasarkan pada pasal 171 HIR dan pasal 1907 Kitab Undang-Undang Hukum Perdata.

${ }^{61}$ Dikutip dari salinan putusan No. 1538/Pdt.G/2013/PA.Tgrs, h. 50 dari 55
} 
proses dimana nanti menjadi zina. Kalau kita perhatikan Agama Islam melarang kegiatan ini sebagaimana Q.S Al-Isra ayat 32 mengatakan yang artinya "Janganlah kamu mendekati zina, (zina) itu sungguh suatu perbuatan keji dan suatu jalan yang buruk".

Pada analisis selanjutnya penulis berpendapat bahwa konteks pembuktian zina yang membutuhkan 4 orang saksi memang menjadi syarat pembuktian mutlak terhadap alasan perzinaan. hal ini menjadi alasan yang rasional mengingat tuduhan perzinaan adalah tuduhan yang sangat keji sehingga pembuktiannya membutuhkan kesaksian yang sangat mengerti kejadiannya. Hal ini menjadi syarat yang mutlak, mengingat ketentuan ini ada pada ayat suci Al-quran pada surat An-Nur ayat 4 dan ayat 13 dimana tuduhan terhadap zina harus mendatangkan 4 saksi. Penulis coba mengkaji lebih dalam mengenai pembuktian zina, mengingat pada zaman sekarang ini sulit bagi seseorang untuk bisa mengungkap perzinaan dengan mendatangkan 4 saksi. Karakteristik masyarakat yang sudah beralih kepada sikap individualis dan sudah mengedepankan privasi menjadi hal yang sukar untuk bisa membuktikan perzinaan dengan 4 saksi.

Pada prakteknya hanya suami atau isterinya saja yang dapat melihat langsung praktek perzinaan yang dilakukan pasangannya, inipun belum tentu dilakukan secara langsung. Saat ini mengungkap perzinaan dapat dilakukan dengan alat komunikasi (handphone), hal ini dapat terjadi bila pelaku zina itu mendokumentasikan perzinaannya. Kalau diperhatikan banyak cerita perzinaan seperti video, foto, bahkan gambar-gambar pornografi yang beredar dimasyarakat melalui handphone. Itu semua dapat diuji kebenarannya secara forensik oleh ahli di bidang IT. Seperti contoh dulu ada video perzinaan yang melibatkan publik figure di Indonesia, dan video itu dalam waktu yang singkat menyebar di masyarakat Indonesia. Terhadap video itu apakah masih memerlukan kesaksian 4 orang saksi ?.

Sebagai contoh penulis coba memberikan gambaran apabila seorang mencurigai suami atau isteri dari saudaranya berbuat zina, ia mengikuti suami atau isteri saudaranya itu ke sebuah kamar dan mendapatinya masuk bersama laki-laki/wanita lain sedangkan ia hanya seorang diri. Lalu ia mendokumentasikan oral seks yang dilakukan suami atau isteri saudaranya tersebut dengan handphone yang ia miliki, apakah terhadap kasus seperti ini dapat dikatakan zina dan juga memerlukan kesaksian 4 orang saksi?. Kasus seperti ini patut dijadikan kajian kontemporer mengingat pendokumentasian video, foto, gambar melalui handphone belum ada dizaman Rasulullah SAW. 
Ada rekomendasi kontemporer yang coba penulis kaji pada penelitian ini yaitu hakim menerapkan praktek mashalah mursalah, praktek dimana mencari hukum terhadap oral seks yang tidak ada kejelasan secara hukumnya untuk dijadikan alasan zina. dalil didalam Al-quran tidak dinyatakan jelas mengenai oral seks, hanya dijelaskan “jangan mendekati zina” pada Q.S Al-Isra ayat 32. Dari sisi pendapat ulama sendiri oral seks masih menjadi kajian yang menimbulkan perbedaan pendapat sebagaimana dijelaskan penulis sebelumnya. Pada kasus perbuatan oral seks yang dijadikan perilaku zina, dimungkinkan sulit untuk menggunakan metode qiyas karena ada perbedaan antara dalil Al-qurannya dan ijma. ${ }^{62}$ Dengan mashalah mursalah tentu ini dapat dijadikan alternatif dasar hakim berijtihad dalam mencari sisi oral seks dalam pembuktian zina. pendapat dari

Syeik Ahmad Kutty dosen hukum Islam di Islamic Institute of Toronto, Ontario, Canada mengatakan bahwa oral seks yang dilakukan bukan dari pasangan nikahnya dan itu menimbulkan kepuasan dan hubungan yang intim secara sederhana itu dikatakan sebagai zina. hal ini didasari atas nafsu syahwat dalam melakukan oral seks, nafsu syahwat itulah yang dikatakan zina. ${ }^{63}$

Peranan hakim dituntut untuk bisa mencari suatu kebenaran dalam memutus sebuah perkara atau kasus. Hakim Pengadilan Agama adalah representasi dari pemberlakuannya hukum Islam di Indonesia. Dasar hukum yang digunakan menggunakan 2 landasan hukum yaitu hukum positif dan fiqih. Dasar hukum fiqih yang dijadikan pertimbangan hakim akan menjadi sebuah putusan Pengadilan Agama, putusan Pengadilan Agama adalah representasi hukum Islam di Indonesia. Tetapi penerapan hukum Islam dari sebuah putusan Pengadilan Agama hanya berlaku dan mengikat bagi mereka yang berperkara saja. ${ }^{64}$ Artinya peranan hakim dalam membuat putusan tidak hanya berdasarkan pada keyakinan hakim, landasan positif, landasan fiqih, tetapi juga perlu melihat masalah kontemporer yang timbul dimana itu berkaitan dengan kasus yang dihadapi.

Peranan hakim dalam memutus perkara didalam Islam mengacu pada Q. S AlIsra ayat 36 yang artinya “dan janganlah kamu mengikuti apa yang kamu tidak

62 Amir Syarifuddin, ushul fiqih, Kencana, Jakarta, 2009, h. 345-346.

63 Syeikh Ahmad Kutty, Oral sex considered zina? lihat pada http://prophetmuhammadforall com/media/fatawa/oralsexzina.pdf artikel diakses pada 10 April 2015

64 Umar Haris Sanjaya, Muamalah, Bahan Ajar kuliah, Fakultas Hukum, Universitas Islam Indonesia, 2016, hlm. 28 . 
mempunyai pengetahuan tentangnya. Sesungguhnya pendengaran, penglihatan, dan hati, semuanya itu akan diminta pertanggungjawabannya". Maksud dari ayat ini adalach hakim wajib mencapai kebenaran materiil dalam memutus perkara. Islam tidak membedakan antara kebenaran materiil dan kebenaran formil, tetapi yang dicari adalah kebenaran yang sebenarnya sesuai tujuan Islam. Oleh karena itu hakim wajib menggali peristiwa yang terjadi sebenarnya, kemudian bila telah memiliki gambaran yang jelas maka ia boleh memberikan putusan. ${ }^{65}$

\section{KESIMPULAN}

Dengan metode penelitian yuridis normatif hasil kesimpulan yang didapat adalah hakim memberikan pertimbangan hukum zina berdasarkan normatif syar'I. hakim memberikan 4 pertimbangan didalam putusannya yang semuanya menunjukkan pada perbuatan perzinaan yang tidak sampai kepada masuknya alat kelamin pria kedalam wanita. Hal itu dibuktikan dengan foto melalui BBM dan SMS tetapi itu tidak cukup untuk dapat dikatakan zina berdasarkan syariah. Dari sisi kesaksian zina harus dibuktikan 4 orang saksi. Zina dimaknai hakim sebagai persetubuhan dengan masuknya kelamin pria kedalam wanita, dan pembuktiannya tetap harus menghadirkan 4 orang saksi.

Perilaku oral seks yang dilakukan bukan oleh pasangan suami istri tidak dapat dikatakan sebagai zina, karena zina harus terjadi masuknya kelamin pria kedalam kelamin wanita. Oleh karena itu oral seks tidak dapat diklasifikasikan kedalam kata zina, ini lebih kepada perbuatan melebihi batas moral etika perkawinan dalam islam. Oleh karena itu hasil penelitian menemukan bahwa oral seks demi hukum tidak dapat dikatakan sebagai zina, tetapi perbuatan itu masuk kedalam unsur zina. Pembuktian zina hanya dapat diakui bila terjadinya hubungan badan masuknya kelamin pria kedalam kelamin wanita. Secara kesimpulan penelitian ini, hakim memaknai kata zina sepanjang pengertian zina semata, padahal perilaku zina saat ini sudah banyak berbeda baik pola dan tindakannya. Hakim sepatutnya tidak hanya melihat peraturan semata dalam membuat pertimbangan, tetapi melihat perilaku atau pola zina yang dilakukan dalam memaknai kata zina.

\section{Saran}

${ }^{65}$ Asadullah Al-faruq, Hukum Acara Peradilan Islam, Pustaka Yustisia, Yogyakarta, 2009, h. 107. 
Sudah tertulis jelas didalam Ayat suci Al-Quran mengenai pembuktian zina yang harus dilakukan oleh 4 orang saksi, dan hal ini tentu tidak dapat dikesampingkan. Sebagai permasalahan kontemporer menurut penulis, penulis berpendapat bahwa pembuktian zina pada saat ini cukup sulit untuk bisa menghadirkan 4 orang saksi. Alat komunikasi pada saat ini yang sudah modern secara jelas bisa membuktikan kejadian itu bila itu di foto atau di video sepanjang itu telah dibuktikan keoriginalitasnya di bidang forensik IT. Sepanjang itu dapat dibuktikan, sepatutnya pembuktian perzinaan tidak diragukan lagi walaupun tanpa harus menghadirkan 4 saksi keempat-empatnya.

Saran yang selanjutnya akan lebih bijak majelis hakim memberikan saran untuk dilakukan sumpah li'an dari istri kepada suami. Walaupun secara normatif syar'I li'an seharusnya hanya dilakukan suami yang menuduh istri berzina dengan keyakinan. Tetapi dalam konteks istri yang menuduh suami juga layak dilakukan li'an, karena istri yakin dan bahkan dapat membuktikannya walaupun melalui IT.

Perilaku seks sekarang juga sudah berkembang dan tidak monoton pelampiasan hawa nafsu syahwat harus dilakukan dengan persetubuhan saja. Jika itu dapat dikaji lebih dalam, sepatutnya perluasan makna zina perlu dikaji lebih dalam, mengingat bagaimana perasaan seorang istri atau suami yang melihat pasanganya melakukan oral seks kemudian ketahuan dan ingin bercerai dengan alasan zina justru akhirnya ditolak oleh hakim.

\section{DAFTAR PUSTAKA}

Ainul Ghurri, Pemenuhan Kebutuhan Seksual dengan cara oral studi terhadap fatwa syaikh an-najmi dalam tinjauan hukum islam, skripsi, Fakultas Syari'ah, Universitas Islam Negeri Sunan Kalijaga, 2008

Amir Syarifuddin, Hukum Perkawinan Islam Di Indonesia, Ctk. Pertama, Prenada Media, Jakarta, 2006

Amir Syarifuddin,Hukum Perkawinan Islam di Indonesia (Antara Fiqh Munakahat dan UU Perkawinan, Prenada Media, Jakarta, 2006

Amir Syarifuddin, ushul fiqih, Kencana, Jakarta, 2009

A. Djazuli, Fiqh Jinayah (Upaya Menanggulangi Kejahatan dalam Islam), Ctk. Kedua, PT. Raja Grafindo Persada, Jakarta, 1997Ali Zainudin, Hukum Pidana Islam, Sinar Grafika, Jakarta, 2007

Asmu'I, oral seks dalam pandangan hukum islam dan medis, abla publisher, Jakarta,2004

Arwani, Zina dan Kumpul Kebo dalam Perspektif Hukum Islam, Studi atas delik zina dan kumpul kebo dalam RUU KUHP 2005, skripsi, Fakultas Syariah, Universitas Islam Negeri Sunan Kalijaga, 2008 
Fauzan Al-anshari Abdurrahman Madjrie, Hukuman bagi pezina dan penuduhnya, Kahirul Bayan, Jakarta, 2002

Haliman, Hukum Pidana Sjari'at Islam Menurut Adjaran Ahlus Sunnah,Ctk. Pertama, BulanBintang, Jakarta,

Ibnu Qayyim Al-Jauziyah, Hukum Acara Peradilan Islam, Ctk. Kedua, Pustaka Pelajar, Yogyakarta, 2007

Iin Ernawati, Oral seks di dalam perkawinan dalam pandangan masyarakat serta kedudukannya menurut perspektif hukum Islam studi kel. Ciater kecamatan serpong, skripsi, Fakultas Syari'ah dan Hukum, Universitas Islam Negeri Syarif Hidayatullah, Jakarta, 2007

Kompilasi Hukum Islam

Marzuki Umar Sa'abah, Seks dan kita, Gema Insani Press, Jakarta, 2008

M. Yahya Harahap, Kedudukan Kewenangan Dan Acara Peradilan Agama, Ctk. Keempat, Sinar Grafika, Jakarta, 2007

Muhammad Saifullah, Mohammad Arifin dan Ahmad Izzauddin, Hukum Islam Solusi Permasalahan Keluarga, Ctk. Pertama, UII Press, Yogyakarta, 2005

Muhammad Syaifuddin, Sri Turatmiyah, Annalisa Yahanan, Hukum Perceraian, Ctk. Kedua, Sinar Grafika, Jakarta, 2014

Neng Djubaedah, Perzinaan Dalam Peraturan Perundang-undangan di Indonesia Ditinjau dari Hukum Islam, Ctk. Pertama, Kencana Prenada Media Group, Jakarta, 2010

Peraturan Pemerintah Nomor 9 Tahun 1975 Tentang Pelaksanaan Undang-Undang Nomor 1 Tahun 1974 Tentang Perkawinan

Riyanto Adi, Metodologi Penelitian Sosial dan Hukum. Jakarta, Graint 2004

Singgih D. Gunarsa, Psikologi Praktis : Anak, Remaja, dan Keluarga, BPK Gunung Mulia, Jakarta, 1991

Sosilo, KUHP dan KUHAP, Buana Press, Jakarta, 2008

Sri Mamudji, et, al., Metode Penelitian dan Penulisan Hukum, Badan Penerbit Fakultas Hukum Universitas Indonesia, Jakarta, 2005

Suharsimu Arikunto, Prosedur Penelitian Suatu Pendekatan Praktek, Rineka Cipta, Jakarta, 1996

Subekti, Pokok-Pokok Hukum Perdata, Ctk. Ketujuh Belas, PT. Intermasa, Jakarta, 1983, Hlm. 42Jakarta, 1983

Soerjono Soekamto. Penelitian Hukum Normatif (Suatu Tinjauan Singkat)” ,PT Raja Grafindo Persada, Jakarta,2007

Soerjono Soekanto, Sri Mamudji, Penelitian Hukum Normatif Suatu Tinjauan Singkat, Raja Grafindo Persada, cet. 10, Jakarta, 2007

Tamar Djaja, Tuntutan Perkawinan \& Rumah Tangga Islam, Ctk. Kedua, PT. Alma'arif, Bandung, 1982

Umar Haris Sanjaya, Muamalah, Bahan Ajar kuliah, Fakultas Hukum, Universitas Islam Indonesia, 2016

Asadullah Al-faruq, Hukum Acara Peradilan Islam, Pustaka Yustisia, Yogyakarta, 2009 Undang-Undang No. 11 tahun 2008 tentang Informasi dan Transaksi Elektronik 
Wahbah Az-Zuhaili, Fiqih Islam Wa Adillatuhu, Ctk. Kesepuluh, Gema Insani, Jakarta, 2007

Putusan No.1538/Pdt.G/2013/PA.Tgrs

Quraish shihab, anda bertanya, quraish menjawab berbagai masalah keislaman, AlBayan, Bandung, 2003,

http://news.detik.com/berita/2517113/meski-ada-bukti-foto-pesta-seks-

majelishakim-tolak-gugatan-perceraian, artikel diambil pada 10 April 2015, $09.00 \mathrm{WIB}$

Syeikh Ahmad Kutty, Oral sex considered zina ? lihat pada http://prophetmuhammadforall com/media/fatawa/oralsexzina.pdf artikel diakses pada 10 April 2015. 